\title{
REVITALISASI TRADISI MASSOLO PADA UPACARA KEMATIAN DI DESA BAEBUNTA (DALAM PERSPEKTIF DAKWAH)
}

\author{
Muhazzab Said \\ Institut Agama Islam Negeri (IAIN) Palopo \\ email : muhazzab.iain@gmail.com
}

\begin{abstract}
In the social sciences, tradition is defined as customs, religious rituals, and sacred ceremonies of a particular group of people. Massolo' in Baebunta is indeed a habit, customs, even can be said religious rituals performed on every death of a family member. Based on the purpose and usefulness, massolo tradition 'is a positive thing, because in it there are elements of help to help each other as long as the action is based on sincere intention and not forced. But whatever the motive, the massolo' tradition needs to be revitalized, straightened and preserved.
\end{abstract}

Key Words: Da'wah, Massolo', Tradition, Death Ceremony

\begin{abstract}
Abstrak
Dalam ilmu-ilmu sosial, tradisi diartikan sebagai kebiasaan, adat-istiadat, ritual keagamaan, dan upacara-upacara sakral suatu kelompok masyarakat tertentu. Massolo' di Baebunta memang merupakan kebiasaan, adat istiadat, bahkan bisa dikatakan ritual keagamaan yang dilakukan pada setiap ada peristiwa kematian salah seorang anggota keluarga. Berdasarkan tujuan dan kemanfaatannya, tradisi massolo' merupakan suatu hal yang bernilai positif, karena di dalamnya ada unsur tolong menolong antar sesama selama perbuatan itu didasarkan atas niat yang ikhlas serta tidak dipaksakan. Tetapi apapun motifnya, tradisi massolo' perlu dilakukan revitalisasi, diluruskan dan dilestarikan pelaksanaannya.
\end{abstract}

Kata Kunci: Dakwah, Massolo', Tradisi, Upacara Kematian,

\section{PENDAHULUAN}

Perkembangan agama Islam sejak awalnya, menyebar pada komunitas yang umumnya telah memiliki tradisi atau adat istiadat yang sudah berakar dan diwarisi secara turun-temurun dari nenek moyang mereka ${ }^{1}$. Oleh karena itu, Islam ketika berhadapan dengan adat yang sudah mapan dituntut menunjukkan kearifannya. Dan ternyata Islam dalam realitasnya mampu menampakkan

\footnotetext{
${ }^{1}$ Rahimin, et al., Harmonisasi Agama dan Budaya Indoensia (Cet. I; Jakarta: Balai Penelitian dan Pengembangan Agama, 2009), h. 3.
} 
kearifannya, yang ditandai dengan pendekatan dakwah secara damai dan bertahap, bukan sebaliknya dengan cara frontal sporadik disertai kekerasan, karena Islam adalah agama damai dan menganjurkan perdamaian.

Walaupun di Sulawesi Selatan terdapat beberapa bahasa daerah yang menjadi jati diri kedaerahan yang berbeda antara satu daerah dengan daerah yang lain, misalnya bahasa Bugis, bahasa Makassar, bahasa Toraja, dan bahasa Luwu, namun masuknya Islam di daerah ini penuh dengan kedamaian. Salah satu tradisi yang ada di Sulawesi Selatan ialah Massolo' yang, merupakan budaya lokal (local culture) yang sudah terakulturasi dengan budaya Islam yang telah berurat berakar dalam masyarakat, sehingga tampak budaya lokal tersebut seakan-akan merupakan bagian dari ajaran Islam.

Baebunta yang menjadi lokasi peneitian ini merupakan salah satu dusun yang berada di bawah pemerintahan Kabupaten Luwu Utara Provinsi Sulawesi Selatan. Di dusun tersebut terdapat suatu tradisi lokal yang sudah memasyarakat secara turun temurun yang dikenal dengan istilah massolo ${ }^{2}$ yang dilakukan oleh masyarakat setempat ketika terjadi musibah kematian salah satu anggota keluarga masyarakat tersebut. Baebunta adalah masyarakat adat yang sampai sekarang masih memiliki struktur adat dan bahasa yang permanen, di mana penduduknya semuanya beragama Islam terkenal sebagai masyarakat yang taat beragama walaupun adat ikstiadat tetap dipertahankan dan dijalankan.

Tradisi massolo' di Baebunta merupakan adat kebiasaan yang sudah mentradisi secara turun temurun sejak berabad-abad lamanya. Tradisi massolo' ini dilakukan apabila terjadi suatu musibah kematian salah seorang yang berdomisili di Baebunta maka masyarakat setempat secara spontan datang berduyung-duyung ke rumah duka dengan membawa sumbangan dalam bentuk bahan makanan. Para tamu yang membawa sumbangan ini disambut secara adat oleh keluarga berduka sebagai penghormatan. Adapun tujuan sumbangan tersebut adalah untuk keperluan menjamu para tamu yang datang melayat pada hari kematian tersebut yaitu mulai pada hari persiapan pemakaman sampai dengan tiga hari berturut-turut. Menurut kebiasaan, sejak hari pertama hingga hari ketiga para keluarga maupun tetangga datang berkumpul di rumah duka

2 "Massolo'" adalah istilah lokal yang berarti memberikan sumbangan. Pada setiap terjadi musibah kematian di Baebunta khususnya, biasanya dilakukan upacara minimal tiga malam berturut-turut untuk mengenang dan mendoakan arwah keluarga yang telah meninggal, dan untuk menunjang pelaksanaan upacara itu masyarakat secara sukarela datang " massolo" " ke rumah duka dengan membawa sumbangan dalam bentuk uang terutama dalam bentuk makanan, seperti : beras, gula, terigu, minyak kelapa, sagu, dan lain-lain. 
untuk menghibur dan sekaligus dilakukan pengajian minimal menammatkan alQur'an satu kali secara bersama-sama, dan pada malam harinya seperti juga di tempat-tempat yang lain diadakan dakwah (ceramah agama) oleh ulama atau muballigh sebagai pencerahan batin bagi keluarga yang berduka maupun para keluarga dan tamu yang datang.

Pada saat ada seperti ini, kekeluargaan dan kegotongroyongan di Baebunta nampak kental sekali, karena tanpa dipanggil dan diundang masyarakat sekitar datang secara sendiri-sendiri atau secara bersama-sama untuk membesuk dan sekaligus memberikan bantuan baik dalam bentuk material maupun dalam bentuk non- material seperti mendirikan tenda, membawa kursi dan peralatan lain dari rumahnya sendiri, ada yang membuat papan mayat (istilah lokalnya "duni"), dan keranda, ada yang pergi menggali kuburan, dan lain-lain bantuan yang diberikan tanpa diminta.

Menurut kebiasaan masyarakat setempat, apabila seorang keluarga meninggal dunia, seluruh keluarga, handai tolan, tetangga dekat dan jauh dalam kampung itu datang membawa " passolo" " sebagai tanda belasungkawa dan turut berduka cita dengan membawa berbagai macam bahan makanan yang akan disajikan kepada para tamu yang datang melayat. Bahkan sanak saudara yang jauh pun apabila mengetahui adanya kematian anggota kelaurga di Baebunta juga datang atau mengirimkan sesuatu sebagai tanda belasungkawa.

Pada hari pertama sesudah jenazah dimakamkan, para tamu yang datang melayat, dijamu dengan minuman atau makanan yang diambil dari passolo' tadi. sehingga taradisi ini dapat dikatakan tidak merepotkan keluarga yang berduka, karena pada dasarnya makanan yang dimakan oleh para tamu itu adalah hasil masakan oleh ibu-ibu yang datang untuk keperluan itu dan bahan makanannya diambil dari hasil massolo' yang terkumpul tadi.

Dengan demikian, massolo' merupakan tradisi yang bernilai positif karena mengandung unsur taawun dan tasamu, yaitu unsur saling bantu membantu dan tolong menolong antara satu keluarga dengan keluarga lain yang ditimpa musibah. Ini berarti bahwa di dalam tradisi massolo' terdapat unsur dakwah, yaitu implementasi dari ajaran Islam anatara lain saling tolong menolong dan saling membantu antara sesama manusia khususnya sesama muslim sebagaimana yang terkandung dalam firman Allah dalam Q.S. al--Maidah/5:2

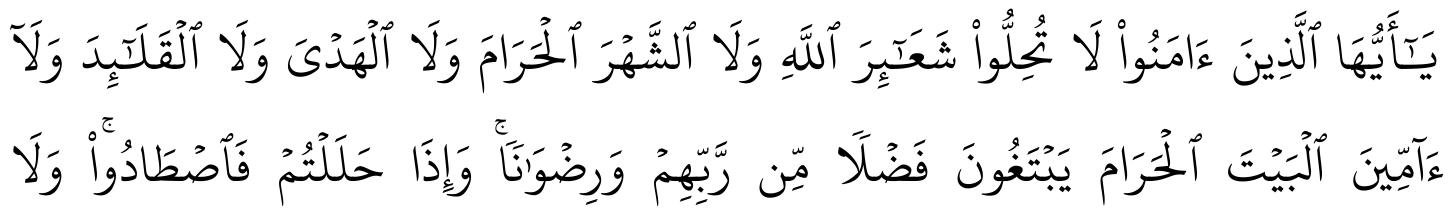




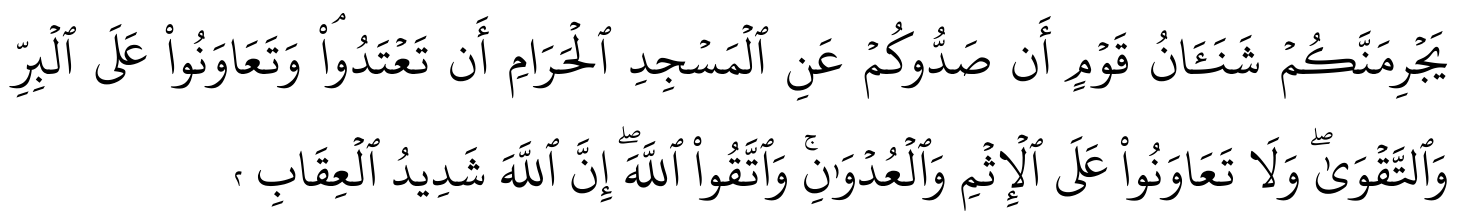

Terjemahnya :

... dan bertolong-tolonganlah kamu dalam (mengerjakan) kebaikan dan takwa, dan jangan tolong menolong dalam berbuat dosa dan permusuhan. Bertkawalah kepada Allah , sungguh Allah sangat berat siksanya. ${ }^{3}$

Berdasarkan pandangan-pandangan yang dikemukakan di atas, dipandang perlu melakukan penelitian untuk melihat eksistensi tradisi massolo, serta bagaimana perspektif dakwah terhadap tardisi massolo' tersebut. Penelitian ini diharapkan dapat memberikan masukan bagi masyarakat Baebunta pada umumnya dan pemangku adat khususnya untuk lebih melestarikan tradisi massolo' karena mengandung manfaat serta nilai-nilai kebersamaan dan kekeluargaan dalam kehidupan bermasyarakat dan beragama.

Adapun ruang lingkup penelitian ini terfokus pada pembahasan sekitar perspektif dakwah terhadap tradisi massolo', bagaimana dakwah melihat tradisi massolo' bukan semata-mata dari segi tradisinya, tetapi yang lebih penting adalah apakah tradisi massolo' tersebut dapat berfungsi sebagai media dakwah kultural yang perlu dikembangkan dalam rangka pembinaan umat, dan bagaimana melakukan revitalisasi terhadap tradisi massolo' sehingga dalam pelaksanaannya tidak melenceng dari ajaran Islam.

\section{METODE}

Pendekatan yang digunakan untuk menjawab permasalahan dalam penelitian ini adalah pendekatan sosiologis, psikologis, dan komunikasi. Penelitian ini merupakan penelitian lapangan yang bersifat deskriptif kualitatif, dimaksudkan untuk pengukuran yang cermat terhadap fenomena sosial teretentu, di samping untuk medeskripsikan gejala-gejala yang terjadi. Pemaparan hasil temuannya dilakukan secara sistematik dengan menekankan pada data faktual yang hanya melibatkan satu variabel. Dengan demikian, penelitian ini merupakan pengembangan konsep dan menghimpun fakta tetapi tidak melakukan pengujian hipotesis, dan karenanya tidak diperlukan adanya hipotesis.

\section{h. 142 .}

${ }^{3}$ Departemen Agama RI, Al-Qur'an dan Terjemahnya (Semarang: Karya Toha Putra, 2002), 
Penelitian ini mengambil lokasi di Desa Baebunta salah satu desa yang berada di Kabupaten Luwu Utara yang penduduknya mayoritas beragama Islam tetapi memiliki tradisi dan adat istiadat. Salah satu di antara tradisi yang sering dilakukan adalah massolo' pada upacara kematian.

Sumber data yang digunakan adalah data primer yang diperoleh melalui studi lapangan (field research) dan data sekunder yang dikumpulkan melalui studi pustaka (libray research) berupa literatur, konsep, teori, dan karya ilmiah lainnya yang berhubungan dengan masalah yang diteliti. Informan kunci atau subjek dalam penelitian ini adalah mereka yang dianggap memahamai masalah adatistiadat atau tradisi massolo' di Desa Baebunta yaitu : Kepala Desa, Imam Desa, Pemangku-pemangku Adat (seperti Pabbicara, Makole, Balailo), tokoh-tokoh agama dan adat lainnya yang ada di Baebunta. Teknik yang digunakan untuk mengumpulkan data dalam penelitian ini adalah observasi dan wawancara.

\section{EKSISTENSI MASSOLO' PADA UPACARA KEMATIAN DI BAEBUNTA}

Tidak ada catatan tertulis yang mengungkapkan sejak kapan upacara massolo' mulai dikenal dan dilaksanakan di Baebunta. Namun disebut-sebut oleh para pemangku adat bahwa tradisi massolo' ini telah ada sejak zaman dahulu kala bahkan sebelum masuknya agama Islam di wilayah ini, dan masih berlangsung secara turun temurun hingga saat ini.

Istilah massolo' adalah merupakan bahasa lokal daerah Sulawesi-Selatan yang secara etimologi artinya memberikan bantuan atau sumbangan. Menurut istilah, massolo' adalah pemberian bantuan atau sumbangan dalam bantuk uang tunai yang dibawa oleh seseorang kepada keluarga yang melangsungkan upacara resepsi pernikahan. Bantuan atau sumbangan yang diserahkan tersbut dinamakan "passolo"

Di Baebunta, di samping pengertian massolo' seperti yang tersebut di atas, massolo' memiliki arti khusus yakni pemberian bantuan atau sumbangan kepada keluarga yang sedang ditimpa musibah kematian, yang pada umumnya sumbangan tersebut diberikan dalam bentuk bahan makanan seperti beras, gula, terigu, bahkan dalam bentuk hewan ternak baik yang berkaki dua seperti ayam maupun yang berkaki empat seperti kambing, kerbau, atau sapi, dan dilakukan meneurut adat istiadat setempat.

Dengan demikian dapat dipahami bahwa yang dimaksud tradisi massolo'dalam penelitian ini dikhususkan pada upacara adat dalam bentuk gau makarawing, yaitu pemberian bantuan atau sumbangan dalam bentuk bahan makanan sesuai kemampuan dari seseorang atau keluarga khusus kepada keluarga yang ditimpa musibah kematian, dan dilakukan menurut adat istiadat 
setempat. Maksudnya, pihak keluarga yang berduka menerima atau menunjuk satu atau dua orang yang dipercaya menunggu untuk menjemput dan duduk melantai menerima tamu yang datang massolo'. Pada intinya tradisi massolo' adalah sebuah budaya lokal yang telah terbungkus dengan ajaran Islam sehingga seakan-akan telah menjadi budaya Islam masyarakat setempat.

Hal itu merupakan sebagai sebuah kenyataan sejarah sebagaimana yang dikatakan oleh Kuntowijoyo bahwa:

Agama dan kebudayaan dapat saling memengaruhi karena keduanya terdapat nilai dan simbol. Agama adalah simbol yang melambangkan nilai ketaatan kepada Tuhan. Kebudayaan juga mengandung nilai dan simbol supaya manusia bisa hidup di dalamnya. . . . Hanya saja keduanya perlu dibedakan. Agama adalah sesuatu yang final, universal, abadi (parennial) dan tidak mengenal perubahan (absolut), sedangkan kebudayaan bersifat partikular, relatif dan temporer. ${ }^{4}$

Berdasarkan pendapat Kuntowijoyo di atas, dapat ditarik pemahaman bahwa antara tradisi massolo di Babebunta dan ajaran agama Islam terdapat titik kesamaan maka tidak mustahil di situlah terjadi akulturasi timbal balik. Adanya kemungkinan akulturasi timbal balik ini diakui dalam suatu atau ketentuan dasar dalam ilmu Ushul al-Fiqh, bahwa : "Adat itu sumber hukum" (al-'Adah Muhakkamah), atau lebih lengkapnya "Adat adalah syari'ah yang dihukumkan" (al-'Adah syari'ah muhakkamh), artinya adat dan kebiasaan suatu masyarakat yakni budaya lokalnya, adalah sumber hukum dalam Islam. ${ }^{5}$ Bahkan dalam ilmu Ushul Fiqh budaya lokal dalam bentuk adat kebiasaan itu juga disebut 'urf (secara etimologis berasal dari akar kata yang sama dengan ma'ruf). Karena adat suatu masyarakat mengandung unsur yang salah dan benar sekaligus, maka dengan sendirinya orang-orang muslim harus melihatnya dengan kritis, dan tidak dibenarkan sikap yang hanya membenarkan semata, sesuai dengan prinsip Islam itu sendiri yang amat menentang tradisionalisme. ${ }^{6}$ Berkenaan dengan ini, patut direnungkan perintah Allah dalam al-Qur'an tentang argumen yang sering diajukan orang-orang kafir terhadap kebenaran, (Q.S. al-Zukhruf/43:23-24).

${ }^{4}$ Kuntowijoyo, Muslim Tanpa Masjid, Essai-Essai Agama, Budaya dan Politik dalam Bingkai Strukturalisme Transendental, (Bandung: Mizan, 2001), h. 196.

${ }^{5}$ Nurcholish Madjid," Islam Doktrin dan Perdaban Sebuah Telaah Kritis tentang Masalah Keimanan, Kemanausiaan, dan Kemodrenan, (Cet.IV, Jakarta: Yayasan Wakaf Paramadina, 2000), h. 550 .

${ }^{6}$ Lihat Ibid., h. 552. 


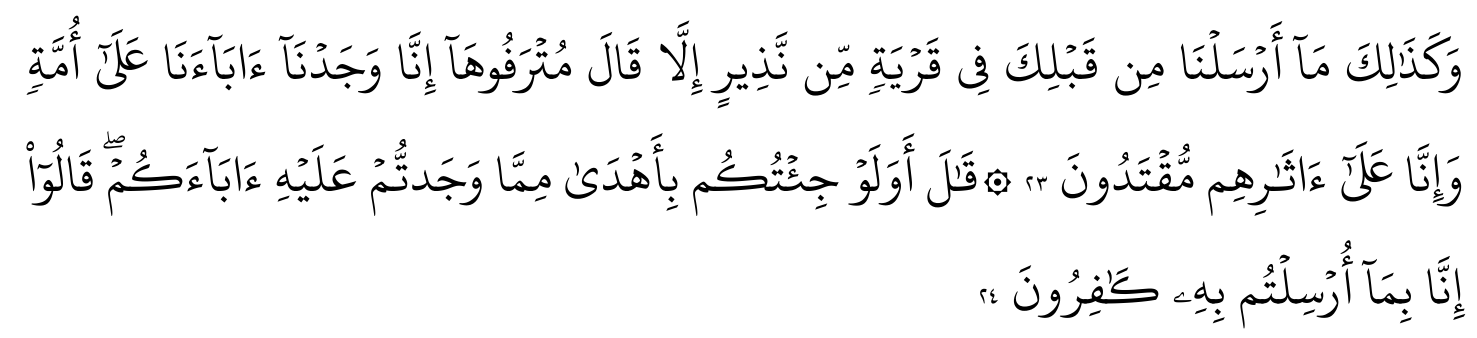

Terjemahnya :

“Demikianlah, Kami tidak mengutus sebelum kamu seorang pemberi peringatan pun dalam suatu negeri, melainkan orang-orang yang hidup mewah di negeri itu berkata: "Sesungguhnya kami mendapati bapak- bapak kami menganut suatu agama dan sesungguhnya kami adalah pengikut jejak-jejak mereka". 24. (Rasul itu) berkata: "Apakah (kamu akan mengikutinya juga) sekalipun aku membawa untukmu (agama) yang lebih (nyata) memberi petunjuk daripada apa yang kamu dapati bapak-bapakmu menganutnya?" mereka menjawab: "Sesungguhnya kami mengingkari agama yang kamu diutus untuk menyampaikannya."7

Firman Allah tersebut di atas menegaskan bahwa Islam menentang tradisionalisme, yaitu sikap apriori memandang tradisi leluhur selalu baik dan harus dipertahankan dan diikuti. Prinsip ini harus diletakkan pada landasan ajaran dasar mengharuskan kita selalu bersikap kritis. Jadi kehadiran Islam selalu merombak tatanan masyarakat atau transformasi sosial dari masa jahiliyah menuju masa yang lebih baik. Namun bukan berarti Islam bersifat disruptif atau menghapus semua kebiasaan atau tradisi masyarakat dengan fundamental. Islam tetap melegalisir kebiasaan suatu masyarakat selama tradisi itu tidak bertentangan dengan hukum-hukum syari'at.

Dalam menyikapi budaya lokal, kita harus melihat apakah budaya lokal itu sifatnya "tradisi" atau bersifat "tradisionalitas" sebagaimana pendapat Nurcholis Madjid yang telah dikemukakan di muka, termasuk "massolo" yang menjadi budaya lokal bagi masyaraakat Baebunta. Sebab, walaupun massolo' ini memiliki tujuan yang mulia sebagaimana yang disebutkan di atas, dalam pelaksanaan massolo' ini tidak tertutup kemungkinan masih ada sebagian masyarakat hanya ikut-ikutan karena tradisi semata. Maksudnya, mereka ramairamai turut membawa passolo hanya sebatas untuk melestarikan tradisi yang sudah diwariskan oleh para pendahulunya. Walaupun pada hakikatnya mereka tidak mengetahui secara persis apa tujuan dan fungsi dari kegiatan tersebut, namun mereka tidak akan rela jika kegiatan tersebut ditiadakan.

${ }^{7}$ Departemen Agama RI., Al-Qur'an dan Terjemahnya. (Semarang: Karya Toha Putra, 2002), h. 704-705. 
Walaupun demikian, local wisdom (kearifan lokal) dapat dipahami sebagai gagasan-gagasan, nilai-nilai, pandangan-pandangan setempat (lokal) yang bersifat bijaksana, penuh kearifan, bernilai baik, yang tertanam dan diikuti oleh anggota masyarakatnya. Kearifan lokal terbentuk sebagai keunggulan budaya masyarakat setempat maupun kondisi geografis dalam arti luas. Kearifan lokal merupakan produk budaya masa lalu yang patut secara terus-menerus dijadikan pegangan hidup. Meskipun nilai lokal tetapi nilai yang terkandung di dalamnya dianggap sangat universal.

Dilihat dari pengertian massolo', maka dapat dipahami bahwa tujuan massolo' yang dilakukan oleh masyarakat Baebunta mengandung nilai-nilai yang sangat positif dan mulia. Dikatakan positif dan mulia karena massolo' tersebut berarti membantu sesama manusia yang ditimpa musibah untuk meringankan beban penderitaan mereka. Kalau begitu, maka kegiatan massolo'yang dilakukan secara adat istiadat pada hakikatnya bertujuan untuk kemanusiaan, yaitu pemberian bantuan kepada sesama manusia terutama yang muslim untuk meringankan beban penderitaan mereka akibat kematian anggota keluarganya. Di samping itu, massolo' juga bertujuan untuk lebih mengeratkan hubungan silaturrahim dan menghibur mereka yang tertimpa musibah, walaupun tanpa membawa passolo'. Terdapat sebuah prinsip lokal yang diperpegangi oleh masyarakat Baebunta yang dalam bahasa daerah setempat mengatakan bahwa : iporio to bawaan labbi iporiopa tau mambawa" maksudnya : Sangat disenangi atau dihargai jikalau sesuatu yang dibawa, tapi lebih disenangi atau dihargai orangnya kalau datang walaupun tidak membawa sesuatu. Prinsip lokal tersebut secara filosfi bahwa tradisi massolo' tidak semata-mata dalam bentuk material, tetapi yang lebih penting adalah kehadiran seseorang sebagai bentuk kepedulian dan kekerabatan untuk lebih memperarat hubungan silaturrahim.

Menurut Kepala Desa Baebunta bahwa pelaksanaan massolo' itu sudah merupakan tradisi yang bernilai positif membantu sesama dalam menghadapi kesulitan yang dialami, di samping itu tradisi massolo' sangat tidak memberati masyarakat yang tidak mampu, karena memang tidak dipaksakan. Karena itu, tradisi massolo' ini harus dilestarikan dan dipertahankan karena mengandung banyak manfaat dalam kehidupan sosial kemasyarakatan dan keagamaan. ${ }^{8}$

Bahan makanan yang dibawa sebagai passolo' tadi bertujuan untuk digunakan menjamu para tamu yang datang melayat, sejak hari pertama pada waktu pemakaman hingga pada malam ketiga dari upacara ta'ziyah. Jadi intinya

8Ukkas, umur 41 Tahun, Jabatan Kepala Desa Baebunta “wawancara” pada tanggal 16 Juni 2014 di Baebunta. 
adalah agar yang berduka tidak terbebani untuk menyiapkan segala sesuatu untuk keperluan acara tersebut, karena pada hakikatnya makanan dan minuman yang disuguhkan adalah berasal dari passolo' yang mereka bawa sendiri. Makanan dan minuman tersebut dipersiapkan oleh keluarga, tetangga, sahabat yang datang secara sukarela untuk membantu. ${ }^{9}$

Nilai kebaikan yang dikandung dalam melakukan upacara tradisional itu mengikat rasa solidaritas warga masyarakat yang merasa memiliki kepentingan bersama. Upacara yang penuh dengan simbol-simbol bermakna itu merupakan penghubung dan alat komunikasi yang lebih akrab antara warga masyarakat. Salah satu budaya lokal Sulawesi Selatan yang terakulturasi dengan Islam adalah "Massolo"

Timbul pertanyaan, bagaimana dengan keluarga yang tidak mampu, apakah harus massolo juga? Menurut penjelasan Andi Masita Kampasu bahwa : Keluarga yang tidak mampu tidak dibebani untuk membawa passolo', karena massolo' itu adalah pemberian atau sumbangan secara sukarela sesuai dengan keikhlasan dan kemampuan masing-masing. Dan juga tidak merupakan hutang keluarga. Bahkan, jika sekiraanya passolo' yang dibawa tadi ada kelebihan setelah upacara ta'ziyah selesai, maka sebagian kelebihan tadi disumbangkan kembali kepada keluarga yang tidak mampu, terutama orang yang datang membantu dengan tenaga. ${ }^{10}$

Dengan demikian, dapat dipahami bahwa tradisi massolo' pada upacara kematian yang dilakukan masyarakat Baebunta dapat dikategorikan sebagai tradisi lokal (local tradition) atau budaya lokal (local culture) yang mengandung nilai-nilai kemanusiaan karena di dalamnya tersirat dan tersurat nilai (value) kemanusiaan, silaturrahim, kegotongroyongan, persaudaraan yang perlu dilestarikan pelaksanaannya, karena ia merupakan kekayaan budaya yang nilainya sangat positif.

\section{PERSPEKTIF DAKWAH TERHADAP TRADISI MASSOLO'}

Bila memperhatikan proses dan bentuk tradisi massolo' yang dilakonkan masyarakat Baebunta yang di dalamnya mengandung nilai-nilai positif, perspektif dakwah dalam tradisi massolo' dapat dikategorikan sebgai media dakwah.

9Zainuddin Dg. Mallawa, umur 75 Tahun, Pemangku Adat dengan jabatan Pabbicara, "wawancara" tanggal 22 Juni 2014 di masjid Nurul Ichsan Bebunta.

${ }^{10}$ Andi Masita Kampasu, unur 60 tahun, Pemangku Adat dengan juabatan Makole Babeunta. "wawancara" pada tanggal 16 Juni 2014 di Baebunta. 
Passolo' yang dibawa masyarakat ke rumah duka pada setiap acara kematian di Baebunta dapat dikatgorikan sebagai media dakwah, sebab dengan passolo' tersebut sebagai media untuk lebih mengeratkan silaturrahim masyarakat setempat karena mereka berkumpul tidak ubahnya seperti orang yang bersaudara. Mereka terlihat betul-betul akrab, saling membantu mengerjakan segala sesuatu yang dibutuhkan dalam acara tersebut. Melalui passolo' yang terkumpul mereka masak bersama, makan bersama. Sesudah itu, mereka mencuci piring bersama dan merapikan segala sesuatu yang diperlukan tanpa terlihat adanya sekat dan perbedaan di antara mereka.

Menurut Muh. Aldjasri, bahwa adat istiadat dan tradisi yang ada di Baebunta, tidak semata-mata merupakan sebagai tradisi, tetapi ia memiliki landasan prinsipil yang diperpegangi dan hal itu tidak boleh bertentangan dengan agama Islam, yaitu : Sipakatau, Siporio Sipakarannu. Artinya, dalam menjalankan adat istiadat itu harus berpedoman pada prinsip saling menghargai, saling menggembirakan, saling menyenangkan, dan saling bantu membantu antara satu dengan yang lain ${ }^{11}$. Karena penduduk Baebunta menganut agama Islam, maka adat istiadat yang dijalankan tidak boleh bertentangan dengan ajaran Islam. Hal itu relevan dengan hasil wawancara penulis dengan salah seorang pemangku adat yang mengatakan bahwa prinsip hidup yang dianut dalam kehidupan bermasyarakat di Baebunta adalah : "Ripattuppu ri adae, ripasanre ri syarae". Artinya segala sesuatu yang dilakukan dalam masyarakat selalu diselaraskan dengan adat istiadat dan dalam menjalankannya harus selalu bersesuaian dengan ajaran agama (Islam) sehingga tidak boleh ada adat istiadat yang bertentangan dengan agama, seperti halnya tradisi massolo'.12

Kaitannya dengan kehidupan beragama, pada dasarnya merupakan kepercayaan terhadap keyakinan adanya kekuatan gaib, atau supernatural yang berpengaruh terhadap kehidupan individu dan masyarakat, bahkan terhadap segala gejala alam. Kepercayaan itu menimbulkan perilaku tertentu, seperti berdoa, memuja, yang menimbulkan sikap mental tertentu, seperti rasa takut, optimis, pasrah, dan lainnya dari individu dan masyarakat yang mempercayainya. Karena itu, keinginan, petunjuk, dan ketentuan kekuatan gaib harus dipatuhi kalau manusia dan masyarakat ingin kehidupan ini berjalan dengan baik dan selamat. Walaupun dalam pandangan individu dan masyarakat modern dianggap

11Muh. Aldjasri Topaewai, umur 70 tahun. Pemangku Adat Baebunta dengan Jabatan Rajeng, "wawancara” pada tanggal 22 Juni 2014 di Baloli.

${ }^{12}$ Andi Masita Kampasu, umur 60 tahun. Pemangku Adat Baebunta dengan jabatan Makole,"wawancara" pada tanggal 16 Juni 2014 di Baebunta. 
aneh, tidak rasional karena mereka selalu dipengaruhi oleh pandangan bahwa sesuatu yang diyakni ada kalau konkret, rasional, atau terbukti secara empirik dan ilmiah.

Namun demikian, kehidupan beragama adalah kenyataan hidup manusia yang ditemukan sepanjang sejarah kehidupan pribadinya. Ketergantungan manusia kepada kekuatan gaib ditemukan dari zaman ke zaman hingga ke zaman modern ini. Karena diyakni kebenarannya, sehingga ia menjadi kepercayaan keagamaan atau kepercayaan religius. Karenanya mereka mengadakan upacaraupacara pada momen-momen tertentu, seperti upacara perkawianan, kelahiran, sunnatan, kematian, dan lain-lain juga berlangsunmg dari dahulu kala sampai pada zaman modern ini. ${ }^{13}$ Tidak terkecuali tradisi massolo' yang ada di Baebunta yang sudah menjadi kebudayaan lokal yang terus menerus berlangsung karenanya terlihat seakan-akan sudah menjadi kebudayaan Islam.

Tradisi Massolo' walaupun sifatnya merupakan adat istiadat masyarakat setempat, dilihat dari perspektif dakwah ia mengandung nilai-nilai luhur dan mulia yang sangat berguna dalam kehidupan sosial kemasyarakatan. Apalagi dalam kehidupan modern seperti sekarang ini di mana dalam masyarakat telah terjadi sekat-sekat antara sikaya dengan simiskin, antara pejabat dengan rakyat biasa, maka dengan tradisi massolo' ini semua sekat-sekat tadi akan cair dengan sendirinya. Karena pada saat itu semuanya duduk melantai, baik yang hadir massolo' maupun tuan rumah terlihat sangat akrab serta tidak ada perbedaan di antara mereka.

\section{PELESTARIAN DAN REVITALISASI TRADISI MASSOLO' PADA UPACARA KEMATIAN DI BAEBUNTA}

Seiring dengan peningkatan teknologi dan transformasi budaya ke arah kehidupan modern serta pengaruh globalisasi, warisan budaya dan nilai-nilai tradisional masyarakat adat tersebut menghadapi tantangan terhadap eksistensinya, termasuk tradisi massolo' yang ada di Baebunta. Hal ini perlu dicermati karena warisan budaya dan nilai-nilai tradisional tersebut mengandung banyak kearifan lokal yang masih sangat relevan dengan kondisi masyarakat Indonesia saat ini, dan seharusnya dilestarikan, diadaptasi atau bahkan dikembangkan lebih jauh. Budaya lahir dan dikembangkan oleh manusia, melalui akal dan pikiran, kebiasaan, dan tradisi. Kebudayaan merupakan hasil belajar yang sangat bergantung pada pengembangan kemampuan manusia yang unik

${ }^{13}$ Bustanuddin Agus, Agama Dalam Kehidupan Manusia: Pengantar Antropologi Agama, (Jakarta: Raja Grafindo Persada, 2006), h. 1-2. 
yang memanfaatkan simbol, tanda-tanda, atau isyarat yang tidak ada paksaan atau hubungan alamiah dengan hal-hal yang mereka pertahankan.

Perbaikan keadaan budaya bangsa adalah tanggung jawab bersama, baik keluarga, sekolah, pranata sosial, maupun masyarakatnya. Salah satu upaya yang harus dilakukan adalah memberikan arahan kepada anak-anak sejak dini. Di sekolah misalnya, usaha ini dapat dilakukan dengan memasukkan unsur-unsur budaya daerah ke dalam kurikulum. Pengintegrasian budaya lokal ke dalam pembelajaran sungguh sangat penting. Hal ini dilakukan dalam upaya penanaman nilai-nilai yang terkandung dalam budaya lokal dan juga sekaligus untuk meminimalisir pengaruh negatif budaya luar khususnya budaya barat. Rasa bangga akan nilai-nilai budaya dan kearifan lokal seharusnya mulai dipupuk sejak dini untuk menghindari krisis identitas dan jati diri generasi muda. Generasi muda memiliki peran yang sangat penting dalam memajukan budaya daerah. Dalam konteks keberlanjutan budaya, apabila generasi muda sudah tidak lagi peduli terhadap budaya daerahnya, maka budaya tersebut akan mati. Namun jika generasi mudanya memilki kecintaan dan keinginan untuk ikut serta dalam melestarikan budaya daerahnya, maka budaya tersebut akan tetap ada dan berkelanjutan pada setiap generasi.

Dengan demikian, pemahaman bahwa setiap etnik lokal memiliki tema kulturalnya sendiri menjadi penting. Pemahaman itu bukan hal yang mustahil karena tema kultural dalam masyarakat etnik tertentu diorganisasikan dalam pola yang dapat dipahami. Dalam rangka pengembangan budaya dan potensi lokal demi pemenuhan fungsi kultural, edukatif, dan ideologis, kita perlu memilih strategi yang tepat dan jitu di antara sejumlah strategi yang tersedia. Adapun strategi yang dapat dijalankan untuk meningkatkan daya tahan budaya lokal antara lain upaya pembangunan jati diri bangsa, termasuk di dalamnya penghargaan pada nilai budaya dan bahasa, nilai-nilai solidaritas sosial, kekeluargaan dan rasa cinta tanah air. Jati diri bangsa sebagai nilai identitas masyarakat harus dibangun secara kokoh dengan menanamkan nilai-nilai kearifan lokal sejak dini kepada generasi muda.

Budaya yang ada pada setiap etnis seperti tradisi massolo' yang mengandung nilai kearifan lokal adalah warisan masa lalu yang berasal dari leluhur dalam berbagai hal sebagai refleksi masyarakat yang mengitarinya. Kearifan lokal sesungguhnya mengandung banyak keteladanan dan kebijaksanaan hidup.

Oleh karena itu, apabila tradisi massolo' ini berpijak pada landasan "ripasanre riadae ripattuppu ri syarae", maka pelaksanaan tadisi massolo' perlu dilakukan revitalisasi melalui islamisasi, sehingga tradisi massolo' ini tidak hanya 
berkisar pada tradisi semata, tetapi bagaimana pelaksanaannya tidak bertentangan dengan ajaran agama Islam serta bisa bernilai ibadah.

Pertama, pelurusan niat (nawaitu). Walaupun niat merupakan pekerjaan hati yang tidak nampak dan tidak dapat diketahui oleh orang lain, tetapi tatacara pelurusan niat bisa disosialisasikan melalui dakwah, khutbah jum'at, ceramah agama, atau lewat pengajian kepada masyarakat Baebunta bahwa massolo' itu walaupun sifatnya tradisi tetapi ia merupakan perbuatan mulia yang diperintahkan agama karena mengandung unsur tolong-menolong, bantumembantu dan silarrahim. Oleh karenanya harus diniatkan untuk mendapatkan pahala di sisi Allah swt. Pelurusan niat tersebut berdasarkan firman Allah dalam Q.S. Al-Bayyinah/98: 5.

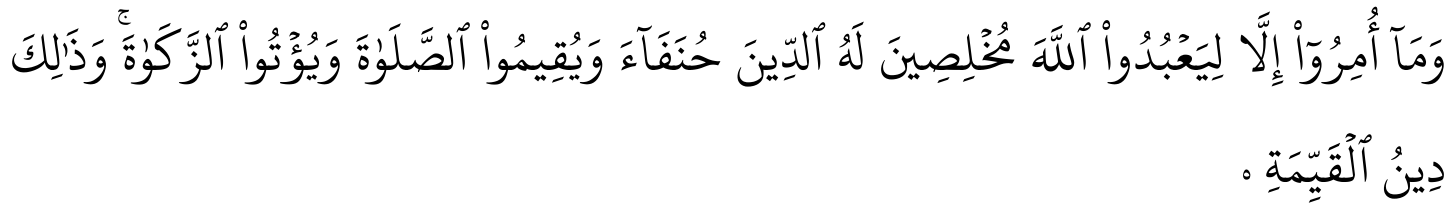

Terjemahnya :

Padahal mereka tidak disuruh kecuali supaya menyembah Allah dengan memurnikan ketaatan kepada-Nya dalam (menjalankan) agama yang lurus... ${ }^{14}$

Bahkan dalam salah satu hadis, Nabi Muhammad saw bersabda yang artinya: Bahwa sesungguhnya setiap amal yang dilakukan harus disertai dengan niat yang baik. (HR. Bukhari Muslim).

Kedua, Kaifiyat atau tatacara pelaksanaannya. Bahwa pelaksanaan massolo' harus dilakukan dengan caracara yang baik dan benar, artinya bahan makanan yang dibawa sebagai passolo' haruslah terdiri dari jenis bahan atau barang yang halal dan bersumber dari yang halal, juga tidak boleh dipaksakan jika yang bersangkutan memang tidak memiliki kemampuan, serta dalam pelaksanaan acara tersebut tidak berlebih-lebihan. Allah swt. berfirman dalam Q.S. al-Furqan / $25: 67$.

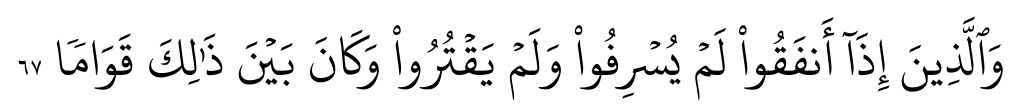

Terjemahnya :

Dan orang-orang yang apabila membelanjakan (harta), mereka tidak berlebihan, dan tidak (pula) kikir, dan adalah (pembelanjaan itu) di tengah-tengah antara keduanya. ${ }^{15}$

14 Departemen Agama RI, Al-Qur'an dan Terjemahnya (Semarang: Karya Toha Putra, 2002), h. 907

15 Ibid., h. 511 
Ketiga tradisi massolo' mempunyai tujuan (gâyat) yang baik, bukan sekedar tradisi dan kebiasaan belaka atau ikut ramai, melainkan bertujuan agar dapat bernilai ibadah untuk mendapatkan pahala di sisi Allah swt.

Menurut penulis, jika tradisi massolo' ini dilakukan berdasarkan ketiga kriteria di muka, yaitu diniatkan dengan hati yang ikhlas, dilakukan dengan tatacara yang baik dan benar serta dilakukan dengan tujuan yang benar, maka dapat dipastikan bahwa tradisi massolo' tidak semata-mata hanya bersifat tradisi, tetapi juga bisa menjadi ibadah gairu mah«ah yang dapat bernilai ibadah serta mendpat pahala dari Allah swt, sebagaimana firman Allah swt. dalam Q.S. Al-Nahl /16: 97.

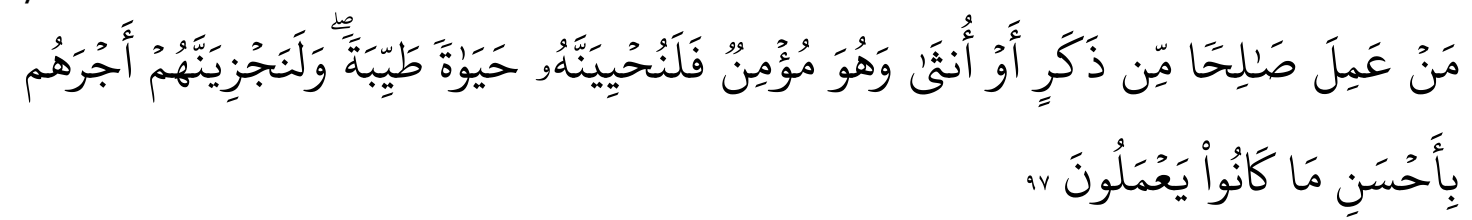

Terjemahnya :

Barangsiapa yang mengerjakan amal saleh, baik laki-laki maupun perempuan dalam keadaan beriman, maka sesungguhnya akan Kami berikan kepadanya kehidupan yang baik dan sesungguhnya akan Kami beri balasan kepada mereka dengan pahala yang lebih baik dari apa yang telah mereka kerjakan. ${ }^{16}$

Di samping itu, nilai-nilai yang terkandung dalam tradisi massolo' tidak terdapat hal yang bertentangan dengan ajaran agama, bahkan sangat relevan. Karena Islam sendiri mengajarkan persaudaraan, tolong-menolong, bantumembantu dan hormat menghormati, sementara pada tradisi massolo' tersebut semua nilai-nilai itu terkandung di dalamnya, sehingga antara tradisi massolo' dengan ajaran Islam tidak perlu dipertentangkan.

Tradisi massolo' yang merupakan budaya lokal di Baebunta, walaupun secara lahiriyah mengandung nilai-nilai positif tetapi perlu dilakukan revitalisasi agar budaya lokal tersebut eksistensinya dapat bertahan. Adapun revitalisasi yang dimaksudkan di sini adalah pelurusan budaya tersebut menjadi sebuah kearifan lokal yang relevan dengan kehidupan beragama.

Berpijak pada pandangan Nurcholis Madjid sebagaimana telah dijelaskan, dalam pandangan penulis, massolo' merupakan budaya atau kearifan lokal (local wisdom) masyarakat Baebunta yang sudah terakulturasi dengan Islam yang tidak perlu dipersoalkan, mengingat bahwa tujuan yang ingin dicapai tidak kontradiktif dengan ajaran Islam. Bahkan di dalamnya termuat nilai-nilai kebaikan yang bersifat universal seperti tolong menolong, bantu membantu, saling bekerjasama,

16Ibid., h. 378-379. 
saling mengharagai antar sesama. Tinggal bagaimana tradisi massolo' ini dilakukan revitalisasi sehingga tidak mengandung unsur-unsur yang tidak relevan dengan ajaran Islam. Dengan demikian, walaupun sifatnya tradisi, tetapi selama pelaksanaannya dilandasi dengan motivasi atau niat (nawaitu) yang baik, diikuti dengan tatacara (kaifiyat) pelaksanaan yang tidak bertentangan dengan ajaran Islam, serta tujuan (gâyat) yang ingin dicapai adalah mengandung kebaikan,

\section{PENUTUP}

Kehidupan manusia dalam suatu masyarakat tidak dapat terlepas dari pengaruh kebudayaan yang mengitarinya. Pola pikir, ucapan, perbuatan, dan berbagai keputusan yang diambil oleh manusia senanantiasa dipengaruhi oleh pandangan budayanya. Yaitu nilai-nilai, aturan, norma, hukum, yang secara selektif dan konsisten digunakan sebagai acuan dalam memecahkan berbagai masalah yang dihadapinya. Perbedaan antara satu kelompok dan kelompok lain dalam menyikapi dan mempersepsi suatu masalah disebabkan karena perbedaan budaya yang dimilikinya.

Tradisi massolo' pada upacara kematian yang ada di Babebunta Kabupaten Luwu Utara merupakan budaya lokal yang mengandung kearifan yang perlu dilestarikan, disamping karena dalam proses pelaksanaannya mengandung unsur-unsur kebaikan yang relevan dengan ajaran Islam, seperti mempererat persaudaraan dan hubungan silaturrahim, tolong-menolong, bantu-membantu, dan sebagainya. Hanya saja dalam pelaksananannya perlu diwaspadai jangan sampai terjadi hal-hal yang bertentangan dengan ajaran Islam, misalnya niat yang tidak ikhlas, kaifiyat (tatacara) yang keliru, atau tujuan yang ingin dicapai bukan karena Allah.

Karena itu, di samping perlu pelestarian, juga diperlukan revitalisasi agar tradisi massolo' tersebut tidak semata-mata bernuansa tradisi, tetapi juga bisa bernilai ibadah gairu mah«ah dengan mengharapkan paahala di sisi Allah swt. Oleh sebab itu, tokoh-tokoh agama Islam, tokoh/pemangku adat seperti Makole, Balailo, Rajeng, dan Pabbicara menurut penulusuran penulis mereka merupakan tokoh-tokoh adat yang memiliki pendidikan yang cukup serta memiliki pemahaman agama yang baik. karena mereka adalah pensiunan guru, bahkan ada yang pensiunan kepala dinas pendidikan dan kebudayaan setempat. Dengan demikian, untuk melestarikan tradisi massolo' yang bermuatan nilai-nilai positif itu, tentu para tokoh adat dan tokoh agama setempat yang diharapkan untuk berperan sehingga kearifan lokal tidak hilang dari kehidupan sosial kemasyarakatan khususnya di Baebunta. 
Mengingat tradisi massolo' mengandung nilai-nilai yang positif, maka disarankan kepada pemangku adat dan pemuka agama Baebunta agar tradisi massolo' ini dapat dilestarikan keberadaannya sebagai suatu kearifan lokal yang memiliki ciri tersendiri yang berbeda dengan budaya lokal lainnya.

\section{DAFTAR PUSTAKA}

Agus, Bustanuddin, Agama Dalam Kehidupan Manusia: Pengantar Antropologi Kuntowijoyo, Muslim Tanpa Masjid, Essai-Essai Agama, Budaya dan Politik dalam Bingkai Strukturalisme Transendental, Bandung: Mizan, 2001.

Badan Pusat Statistik \& Badan Perencanaan Pembangunan Daerah Kabupaten Luwu Utara, Luwu Utara Dalam Angka. Masamba: BPS Kabupaten Luwu Utara, 2013.

..................., Kecamatan Baebunta Dalam Angka. Masamba: BPS Kabupaten Luwu Utara, 2012.

Bungin, Burhan (Ed), Metodologi Penelitian Kualitatif . Cet. IV; Jakarta: Prenada Media Group, 2010.

Departemen Agama RI., Al-Qur'an dan Terjemahnya. Semarang: Karya Toha Putra, 2002,.

Madjid, Nurcholish, Islam Doktrin dan Perdaban Sebuah Telaah Kritis tentang Masalah Keimanan, Kemanausiaan, dan Kemodrenan, Cet.IV, Jakarta: Yayasan Wakaf Paramadina, 2000).

Rahimin, et.al, Harmonisasi Agama dan Budaya di Indonesia Cet. I; Jakarta: Balai Penelitian dan Pengembangan Agama, 2009. 